\title{
Galectin-3-Binding Protein
}

National Cancer Institute

\section{Source}

National Cancer Institute. Galectin-3-Binding Protein. NCI Thesaurus. Code C26351.

Galectin-3-binding protein (585 aa, $\sim 65 \mathrm{kDa}$ ) is encoded by the human LGALS3BP gene.

This protein plays a role in the positive regulation of integrin-mediated cell adhesion. 